\title{
Mycorrhizal colonization and diversity and corn genotype yield in soils of the Cerrado region, Brazil
}

\section{Colonização e diversidade micorrízica e produtividade de genótipos de milho, em solo de Cerrado}

\author{
Sueli da Silva Aquino ${ }^{1}$; Márcia Helena Scabora ${ }^{1}$; João Antonio da Costa Andrade²; \\ Sandra Maria Gomes da $\operatorname{Costa}^{3}$; Kátia Luciene Maltoni²; \\ Ana Maria Rodrigues Cassiolato ${ }^{2 *}$
}

\begin{abstract}
The degree of interaction between arbuscular mycorrhizal fungi (AMF) and host plants appears to depend on plant genotype, which differentially promotes symbiosis and leads to different degree of mycotrophism. The aim of the present study was to assess root colonization, spore density, and diversity of AMF, as well as yield of corn (Zea mays) genotypes in soil from the Cerrado region of Brazil. Number of spores (NS), mycorrhizal colonization (COL), plant and ear height, dry weight (DW), and grain yield (GY) were assessed in inbred lines and their hybrids. Randomized blocks were used for the experimental design, with 30 treatments (genotypes) and three repetitions. The experiment was conducted on the farm of the UNESP-São Paulo State University, Campus of Ilha Solteira, and the plots were composed of two 2-m-long rows, with $0.85 \mathrm{~m}$ between rows, and $0.20 \mathrm{~m}$ between plants. Qualitative and quantitative changes were observed in fungal compositions, as well as preferential associations between symbiotic partners. Analysis of AMF diversity revealed the presence of 12 species, with Scutellospora calospora and Entrophospora colombiana being the most abundant in all treatments. The species Acaulospora longula, Glomus etunicatum, Glomus macrocarpum, and Gigaspora margarita exhibited preferential associations with certain genotypes. COL and GY differed among inbred lines and single-cross hybrids and the significant correlations between COL and the DW and GY showed positive interactions between the plants and AMF. There was no correlation between heterosis for GY and heterosis for colonization. These single-cross hybrids HS83 $\times$ E3 and D3 $\times$ F5 exhibited high GY, evidencing a productivity potential for the low technological condition used.
\end{abstract}

Key words: Zea mays, arbuscular mycorrhizal fungi, single-cross hybrids, inbred lines, species richness

\section{Resumo}

O grau de interação entre o fungo micorrízico arbuscular (FMA) e a planta hospedeira parece depender do genótipo da planta, o qual estimula diferentemente a simbiose, acarretando um menor ou maior grau de micotrofismo. Este trabalho objetivou verificar a colonização radicular, densidade de esporos e diversidade de FMA e produtividade de genótipos de milho, no cerrado. Foram avaliados o número de esporos, colonização micorrízica (COL), altura da planta e da inserção de espiga, massa de matéria seca (MS) e produtividade de grãos (PROD) em linhagens endogâmicas e híbridos. O delineamento

\footnotetext{
${ }^{1}$ Biólogas, Dr ${ }^{\text {as }}$ em Agronomia em Sistemas de Produção, Universidade Estadual Paulista, UNESP, Ilha Solteira, SP, Brasil. E-mail: sueaquino@gmail.com; marcia.scabora@gmail.com

${ }^{2}$ Profs., UNESP, Campus de Ilha de Ilha Solteira, SP, Brasil. E-mail: jandrade@bio.feis.unesp.br; maltoni@agr.feis.unesp.br; anamaria@bio.feis.unesp.br

${ }^{3}$ Prof., Universidade Estadual de Maringá, UEM, Maringá, PR, Brasil. E-mail: smgcosta@uem.br

* Author for correspondence
} 
experimental foi em blocos casualizados, com 30 tratamentos (genótipos) e três repetições. O experimento foi implantado na Fazenda de Pesquisa, Ensino e Extensão da UNESP-Univ Estadual Paulista, Campus de Ilha Solteira, sendo as parcelas constituídas de duas linhas de $2 \mathrm{~m}$ de comprimento, espaçadas de 0,85 $\mathrm{m}$ entre linhas e $0,20 \mathrm{~m}$ entre plantas. Observou-se a ocorreram mudanças qualitativas e quantitativas na composição fúngica, com associações preferenciais entre os genótipos. Para diversidade de FMA foram constatadas 12 espécies, sendo Scutellospora calospora e Entrophospora colombiana as espécies de maior ocorrência para todos os tratamentos. As espécies Acaulospora longula, Glomus etunicatum, Glomus macrocarpum e Glomus margarita exibiram associações preferenciais entre os genótipos. A COL e a PROD diferiram entre linhagens e entre híbridos e as correlações significativas entre COL e a MS e PROD evidenciam interações positiva entre planta e FMA. A heterose para PROD não mostrou correlação com a heterose da colonização. Os híbridos HS83 x E3 e D3 x F5 exibiram alta PROD, evidenciando um potencial produtivo para as condições tecnológicas utilizadas.

Palavras-chave: Zea mays, fungos micorrízicos arbusculares, híbridos, linhagens, riqueza de espécies

\section{Introduction}

Brazil is the third largest producer of corn grain in the world. Corn is cultivated on approximately 12.91 million hectares in each season, behind only the USA and China (INSTITUTO FNP, 2010). In addition to occupying a significant cultivation area in Brazil and generating employment in the primary sector, corn is important for its direct use in human and animal diets, as well as in the industrial production of a variety of everyday products (SCHUCH, 2013). For these reasons, it is currently one of the most studied and improved species.

Cultivation areas in the Cerrado region currently include extensive crops of cereals, legumes, and oilseeds. In Brazil, corn is grown in regions that are under some type of environmental stress, such as the Cerrado region, where small- and medium-scale farmers are responsible for more than $70 \%$ of the production (IBGE, 2008).

Among the microorganisms widely spread in terrestrial ecosystems, arbuscular mycorrhizal fungi (AMF) constitute a key functional group of soil organisms due to their effects on soil properties (RILLIG, 2004; GIANINAZZI et al., 2010). These fungi belong to the Phylum Glomeromycota, Class Glomeromycetes (STÜRMER; SIQUEIRA, 2006), and form symbiotic associations with most land plants. These associations are characterized by the development of highly branched hyphae known as arbuscules in the plant root cortex (GUTJAHR; PARNISKE, 2013). This association is advantageous for AMF, which establish mutualistic symbiotic relationships with the roots of more than $80 \%$ of existing plant species (SMITH; READ, 2008). The abundant fungal mycelia that result from root colonization participate in soil structuring and allow the fungus to absorb a greater amount of mineral nutrients and water (RILLIG; MUMMEY, 2006), which are transferred to the plant host, increasing their photosynthetic activity, enzyme activity, and development.

Specific interactions between fungi and plant genotypes allow the association to be more advantageous, regardless of colonization level. Analysis of fungus-host compatibility and the overall behavior of the interacting species (POUYÚROJAS et al., 2006) indicate differential selectivity in fungus-host relationships and the presence of combinations with a highly variable symbiotic efficiency for the host plants.

The identification of correlations between the fungal characteristics and agronomic properties of specific plants will enable genetic improvements, particularly in rustic genotypes, benefitting farmers using low-cost technology and supplies as in the present study. If corn cultivars respond differentially to root colonization by AMF (REIS et al., 2008), it is important for improvement on breeding programs 
to consider the distinct relationships between corn genotypes and mycorrhizal fungi. Therefore, this study aimed to assess root colination, diversity and spore density of AMF, as well as yield of corn (Zea mays) genotypes in soil from the Cerrado region, Brazil.

\section{Material and Methods}

The experiment was conducted on the farm for Research, Teaching and Extension of the Faculty of Engineering, UNESP-Campus of Ilha Solteira, in the municipality of Selvíria-MS $\left(51^{\circ} 22^{\prime} \mathrm{W}\right.$, $20^{\circ} 22^{\prime} \mathrm{S}$ ), at an altitude of 335 masl. Mean annual temperature is $23.5^{\circ} \mathrm{C}$, and mean annual rainfall is $1.370 \mathrm{~mm}$. The soil was classified as a Hapludox (EMBRAPA, 1999).

The area was originally covered by cerrado sensu stricto; however, it has since been cultivated. During the 2 years preceding the experiment, the area had been under no tillage system, without fertilization, and under a crop-rotation system with corn and Crotalaria juncea. Sowing was performed in December using hand planters and included the application of $20 \mathrm{~kg} \mathrm{ha}^{-1}$ of $\mathrm{N}$ (urea) to the furrow. This was the only fertilization procedure and was intended to simulate low-technology conditions.

Before the start of the experiment, four samples of soil were collected, at a depth of $0 \mathrm{~m}$ to $0.15 \mathrm{~m}$, and each sample comprised 10 individual samples The number of autochthonous AMF spores in the area was determined using part of the samples. Chemical characterization was performed using the remaining material, as described by Raij et al. (2001). The following results were obtained: $\mathrm{pH}$ $\left(\mathrm{CaCl}_{2}\right), 4.5 ; \mathrm{P}\left(\mathrm{mg} \mathrm{dm}^{-3}\right), 20 ; \mathrm{OM}\left(\mathrm{g} \mathrm{dm}^{-3}\right), 21 ; \mathrm{K}$, $\mathrm{Ca}, \mathrm{Mg}, \mathrm{H}+\mathrm{Al}, \mathrm{Al}, \mathrm{BS}$ and $\mathrm{CEC}, 1.4,11,9,42,3$, 22.2 , and $64.2 \mathrm{mmol}_{\mathrm{c}} \mathrm{dm}^{-3}$, respectively, and $\mathrm{V}=35$ (\%).

Randomized blocks were used for the experimental design, with 30 treatments (genotypes) and three repetitions. The plots were composed of two 2-m-long rows, with $0.85 \mathrm{~m}$ between rows, and $0.20 \mathrm{~m}$ between plants. The 30 genotypes used were as follows: ten inbred endogamic lines $\left(\mathrm{S}_{5}\right)$ originated from the Flintisa (F1, F2, F3, F4, and F5) and Dentado (D1, D2, D3, D4, and D5) populations, three lines derived from the ESALQ - PB 1 (E1, E3, and E5) population, three single-cross hybrids of SEMEALI (Sementes Antoniali Ltd) (HS10, HS32, and HS83), five single-cross hybrids (D1 $\times$ F2, D2 $\times$ F4, D3 $\times$ F5, D4 $\times$ F3, and D5 $\times$ F1) and nine threeway cross hybrids (HS10 $\times$ E1, HS10 $\times$ E3, HS10 $\times \mathrm{E} 5, \mathrm{HS} 32 \times \mathrm{E} 1, \mathrm{HS} 32 \times \mathrm{E} 3, \mathrm{HS} 32 \times \mathrm{E} 5, \mathrm{HS} 83 \times$ $\mathrm{E} 1, \mathrm{HS} 83 \times \mathrm{E} 3$, and $\mathrm{HS} 83 \times \mathrm{E} 5$ ).

The Flintisa and Dentado populations were selected for low-technology conditions in an breeding program developed at UNESP, Campus of Ilha Solteira. Flintisa was obtained by recombination with the ESALQ - VF 1, SUWAN and CATETO COLÔMBIA populations, and underwent seven selection cycles before be used to produce the lines. Dentado population was obtained from the Germoplasm collection of the Embrapa-National Center for Research on Corn and Sorghum, Sete Lagoas, MG, and underwent six selection cycles before be used to produce the inbred endogamic lines The ESALQ - PB 1 population was obtained from seven short plant varieties at the Institute of Genetics of ESALQ/USP. The SEMEALI singlecross hybrids represent female parents used in the production of commercial hybrids.

Five plants were randomly selected from the grid 110 days after sowing. Plant height $(\mathrm{PH})$, ear height $(\mathrm{EH})$, and dry weight of the aerial portion (DW) were measured. Grain yield (GY) was calculated using the weight of grains produced in the grid area (grain moisture kept constant at 13\%). EH and GY were measured and corrected to an ideal stand of 20 plants per plot by the covariance method, between GY and the stand.

Fifty-five days after sowing, when the plants developed tassels, a composite sample of 10 
individual samples per block composed of soil and roots, was collected at a depth of $0 \mathrm{~m}$ to $0.15 \mathrm{~m}$ for microbiological analysis. The roots were washed in running water, cleared in a $10 \% \mathrm{KOH}$ solution, acidified with $1 \% \mathrm{HCl}$, stained with $0.05 \%$ trypan blue, and stored in lactoglycerol (PHILLIPS; HAYMAN, 1970). Root colonization was assessed by light microscopy using 100 root segments per repetition. The spores of AMF were counted using a stereoscopic microscope ( $\times 40$ magnification) and $100 \mathrm{~g}$ of soil per sample, from which they were extracted via wet sieving and centrifugation in sucrose $(50 \%)$.

Although AMF spore isolation for quantitative analysis followed the previously described method, but only the soil samples corresponding to the two single-cross hybrids that exhibited the highest grain yields and their parents were used. For the purpose of fungal identification, all spores were collected and transferred to permanent slides prepared using polyvinyl alcohol resin, lactic acid, and phenol (WALKER, 1979). The identification of AMF species was based on the manual by Schenck and Pérez (1990), and on the websites of the International Culture of Collection of Arbuscular Mycorrhizal Fungi (INVAM) (http:// invam.caf.wvu.edu) (maintained by Dr. Joseph Morton), and the Department of Plant Pathology of the University of Agriculture, Szczecin, Poland (maintained by Dr. Janusz Blaszkowski) (http:// www.agro.ar.szczecin.pl/ jblaszkowski/index. html). For statistical analysis, the square mean of treatments was used for the comparison among inbred lines, single-cross hybrids and for the contrast lines versus hybrids, using the F test. The means within each group were compared using the Tukey test, at a significance level of $5 \%$, and Pearson's correlation was calculated among all the assessed characters. Heterosis was calculated relative to the mean of the parents $\left[\mathrm{h}=100\left(\mathrm{~F}_{1}-\right.\right.$ $\left.\left.\left(\mathrm{P}_{1}+\mathrm{P}_{2}\right) / 2\right) /\left(\mathrm{P}_{1}+\mathrm{P}_{2}\right) / 2\right]$ and relative to the superior parent $\left[\mathrm{hs}=100\left(\mathrm{~F}_{1}-\mathrm{P}_{\mathrm{s}}\right) / \mathrm{P}_{\mathrm{s}}\right]$, with regard to grain yield and mycorrhizal colonization in the various crossbreeds. Heterosis relative to the superior parent $\left(\mathrm{P}_{\mathrm{h}}\right)$ was calculated using the formula: hs $(\%)=100\left(\mathrm{~F}_{1}-\mathrm{P}_{\mathrm{h}}\right) / \mathrm{P}_{\mathrm{h}}$, where $\mathrm{F}_{1}$ is the mean of the hybrid, $\left(\mathrm{P}_{1}+\mathrm{P}_{2}\right) / 2$ is the mean of the hybrid's parents, and $\mathrm{P}_{\mathrm{h}}$ is the mean of the best parental performance.

\section{Results and Discussion}

The initial chemical analysis revealed acidic soil conditions, characteristic of soils in the Cerrado region of Brazil. These soils exhibit a high phosphorus (P) adsorption capacity, leading to a low concentration of the soluble element in the soil and a reduced availability to plant roots (CLARK; ZETOS, 1996).

The mean number of AMF spores per $100 \mathrm{~g}$ of soil in the area was 391 before the start of the experiment. After cultivation, the means of the lines and single-cross hybrids were 427 and 468 spores per $100 \mathrm{~g}$ of soil, respectively (Tables 1 and 2). Similar values were reported by Carrenho et al. (2002) in a corn crop (415.2 spores per 100 $\mathrm{g}$ of soil). There were no significant differences that could be attributed to the stability of the communities associated with each genotype. There were significant differences among the lines only with regard to $\mathrm{COL}$, whereas both $\mathrm{COL}$ and $\mathrm{GY}$ exhibited significant differences among the singlecross hybrids. The interaction between lines and single-cross hybrids resulted in significant differences concerning all the attributes, with the exception of NS (Table 1). 
Table 1. Mean values of ear height $(\mathrm{CH})$, plant height $(\mathrm{PH})$, production of dry matter (DW), number of spores (NS), colonization by autochthonous mycorrhizal fungi (COL), and grain yield (GY) in corn breding endogamic lines.

\begin{tabular}{lcccccc}
\hline Lines & $\begin{array}{c}\text { EH } \\
(\mathrm{m})\end{array}$ & $\begin{array}{c}\mathrm{PH} \\
(\mathrm{m})\end{array}$ & $\begin{array}{c}\mathrm{DW} \\
\left(\mathrm{kg} \mathrm{ha}^{-1}\right)\end{array}$ & $\begin{array}{c}\mathrm{NS} \\
\left(100 \mathrm{~g} \mathrm{solo}^{-1}\right)\end{array}$ & $\begin{array}{c}\mathrm{COL}^{(1)} \\
(\%)\end{array}$ & $\begin{array}{c}\mathrm{GY} \\
\left(\mathrm{kg} \mathrm{ha}^{-1}\right)\end{array}$ \\
\hline F3 & 0,89 & 1,77 & 1.337 & 489 & $30,83 \mathrm{a}$ & 3.259 \\
F2 & 0,91 & 1,69 & 2.142 & 343 & $27,60 \mathrm{ab}$ & 2.281 \\
F4 & 0,78 & 1,54 & 1.832 & 484 & $21,70 \mathrm{abc}$ & 2.009 \\
E1 & 0,66 & 1,26 & 2.106 & 441 & $23,92 \mathrm{abc}$ & 1.991 \\
E5 & 0,86 & 1,66 & 1.790 & 483 & $20,50 \mathrm{abc}$ & 1.961 \\
E3 & 0,60 & 1,19 & 1.878 & 434 & $13,33 \mathrm{bc}$ & 1.537 \\
D3 & 0,94 & 1,69 & 2.280 & 466 & $15,67 \mathrm{abc}$ & 1.494 \\
D1 & 0,87 & 1,61 & 2.766 & 436 & $15,66 \mathrm{abc}$ & 1.488 \\
D5 & 0,75 & 1,65 & 1.619 & 403 & $22,83 \mathrm{abc}$ & 1.182 \\
F5 & 0,97 & 1,75 & 1.839 & 480 & $17,08 \mathrm{abc}$ & 1.172 \\
D2 & 0,87 & 1,39 & 1.976 & 384 & $23,25 \mathrm{abc}$ & 1.107 \\
D4 & 0,79 & 1,57 & 1.854 & 397 & $19,08 \mathrm{abc}$ & 1.020 \\
F1 & 0,81 & 1,49 & 2.607 & 308 & $12,16 \mathrm{c}$ & 639 \\
\hline Médias & 0,82 & 1,56 & 2.002 & 427 & 20,28 & 1.626 \\
\hline Valor F & $1,52^{\text {ns }}$ & $2,53^{\text {ns }}$ & $1,28^{\text {ns }}$ & $1,16^{\text {ns }}$ & $3,28^{*}$ & $1,66^{\text {ns }}$ \\
\hline CV $(\%)$ & 12,90 & 9,11 & 16,98 & 3,11 & 7,18 & 20,86 \\
\hline Média geral & 0,95 & 1,78 & 965,34 & 2,65 & 1,36 & $1.214,82$ \\
\hline
\end{tabular}

Means followed by the same letter in a given column did not differ, according to the Tukey test at a probability level of $5 \%$. ${ }^{(1)}$ For statistical analysis the original values were transformed into $\log (\mathrm{x}+1)$.

The comparison between the mean values of COL in the lines showed that lines F3 (30.83\%) and F2 (27.66\%) exhibited the highest values, and F1 (12.16\%) and E3 (13.33\%) the lowest values (Table 1). These results are similar to those obtained by Reis et al. (2008) for corn genotypes tested for $\mathrm{P}$ absorption efficacy, which varied between $31.97 \%$ and $46.91 \%$ when inoculated with Glomus etunicatum.

Although there were no significant differences among lines with regard to GY, the means varied between 3,259 $\mathrm{kg} \mathrm{ha}^{-1}$ (F3 line) and $639 \mathrm{~kg} \mathrm{ha}^{-1}$ (F1 line) (Table 2), and the general mean for the treatments was considered low $\left(1,215 \mathrm{~kg} \mathrm{ha}^{-1}\right)$. The high coefficient of variation was probably a consequence of the different values obtained between the inbred lines (Table 1).

There were differences in the mean COL and GY among the single-cross hybrids (Table 2). The highest and the lowest COL values were observed for the treatments HS83 × E5 (43.92\%) and D1 $\times$ F2 (15.42\%), respectively. The highest mean GY was obtained in the HS83 $\times$ E3 $\left(7,108 \mathrm{~kg} \mathrm{ha}^{-1}\right)$ and D3 $\times$ F5 single-cross hybrids $\left(7,048 \mathrm{~kg} \mathrm{ha}^{-1}\right)$, and the lowest in HS10 $\times$ E1 $\left(3,089 \mathrm{~kg} \mathrm{ha}^{-1}\right)$. The mean GY value was higher in the hybrids than in the lines (1,215 $\left.\mathrm{kg} \mathrm{ha}^{-1}\right)$. Tewari et al. (1993), in a study with millet genotypes inoculated with Glomus caledonium, reported that the plant genotype affected the rate of colonization by AMF and that mycorrhizal efficacy was highly significant to $\mathrm{P}$ absorption, suggesting that the host plant's demand can affect $A M F$ performance.

The relationship between GY and COL observed in the present study has also been reported in wheat (HETRICK et al., 1996) and corn (KAEPPLER et al., 2000) cultivars, respectively. Both authors suggest that selection during genetic improvement 
affects plant-AMF symbiosis due to the generation of cultivars that are less responsive to the fungus. Therefore, the differential symbiotic performance resulting from the interactions between distinct autochthonous AMF populations and species of genetically improved plants should be taken into account when developing current agricultural practices.

Table 2. Mean values of ear height $(\mathrm{CH})$, plant height $(\mathrm{PH})$, production of dry matter (DW), number of spores (NS), colonization by autochthonous arbuscular mycorrhizal fungi (COL), and grain yield (GY) in single-cross hybrid corn genotypes.

\begin{tabular}{lcccccc}
\hline \multicolumn{1}{c}{ Hybrids } & $\begin{array}{c}\mathrm{CH} \\
(\mathrm{m})\end{array}$ & $\begin{array}{c}\mathrm{PH} \\
(\mathrm{m})\end{array}$ & $\begin{array}{c}\mathrm{DW} \\
\left(\mathrm{kg} \mathrm{ha}^{-1}\right)\end{array}$ & $\begin{array}{c}\mathrm{NS} \\
(100 \mathrm{~g} \mathrm{solo})\end{array}$ & $\begin{array}{c}\mathrm{COL}{ }^{(1)} \\
(\%)\end{array}$ & $\begin{array}{c}\mathrm{GY} \\
\left(\mathrm{kg} \mathrm{ha}^{-1}\right)\end{array}$ \\
\hline HS 83 x E3 & 1,11 & 1,96 & 3.674 & 456 & $24,30 \mathrm{abc}$ & $7.108 \mathrm{a}$ \\
D3 x F5 & 1,11 & 2,13 & 3.817 & 378 & $17,33 \mathrm{bc}$ & $7.048 \mathrm{a}$ \\
HS 10 x E3 & 1,17 & 2,08 & 3.365 & 453 & $26,90 \mathrm{abc}$ & $6.107 \mathrm{ab}$ \\
HS 83 x E1 & 1,03 & 1,97 & 4.489 & 578 & $32,60 \mathrm{abc}$ & $6.047 \mathrm{ab}$ \\
HS 32 x E1 & 0,96 & 1,88 & 3.155 & 365 & $35,75 \mathrm{ab}$ & $5.819 \mathrm{abc}$ \\
HS 83 x E5 & 1,02 & 1,89 & 3.594 & 436 & $43,92 \mathrm{a}$ & $5.480 \mathrm{abc}$ \\
HS 32 x E5 & 1,03 & 1,98 & 3.007 & 569 & $33,90 \mathrm{abc}$ & $5.376 \mathrm{abc}$ \\
HS 32 & 1,04 & 1,88 & 3.512 & 537 & $19,60 \mathrm{abc}$ & $5.315 \mathrm{abc}$ \\
HS 10 x E5 & 1,11 & 1,92 & 3.029 & 542 & $21,80 \mathrm{abc}$ & $4.928 \mathrm{abc}$ \\
HS 32 x E3 & 1,11 & 1,95 & 3.627 & 456 & $32,40 \mathrm{abc}$ & $4.915 \mathrm{abc}$ \\
HS 83 & 1,17 & 2,13 & 3.258 & 573 & $28,40 \mathrm{abc}$ & $4.873 \mathrm{abc}$ \\
F3 x D4 & 1,12 & 1,93 & 3.181 & 396 & $25,20 \mathrm{abc}$ & $4.538 \mathrm{abc}$ \\
HS 10 & 1,02 & 2,00 & 3.655 & 435 & $25,30 \mathrm{abc}$ & $4.398 \mathrm{abc}$ \\
D2 x F4 & 0,99 & 1,97 & 3.371 & 434 & $39,00 \mathrm{ab}$ & $4.150 \mathrm{bc}$ \\
F1 x D5 & 0,92 & 1,78 & 3.562 & 446 & $24,30 \mathrm{abc}$ & $3.468 \mathrm{bc}$ \\
D1 x F2 & 0,92 & 1,86 & 3.448 & 409 & $15,42 \mathrm{c}$ & $3.393 \mathrm{bc}$ \\
HS 10 x E1 & 1,01 & 1,89 & 3.404 & 499 & $19,10 \mathrm{abc}$ & $3.089 \mathrm{c}$ \\
\hline Médias & 1,05 & 1,95 & 3.479 & 468 & 27,39 & 5.062 \\
\hline Valor de F & $0,81^{\text {ns }}$ & $0,66^{\text {ns }}$ & $1,05^{\text {ns }}$ & $1,24^{\text {ns }}$ & $3,49^{* *}$ & $4,94^{* *}$ \\
\hline CV (\%) & 12,90 & 9,11 & 16,98 & 3,11 & 7,18 & 20,86 \\
\hline Média geral & 0,95 & 1,78 & 965,34 & 2,65 & 1,36 & $1.214,82$ \\
\hline Means followed by the same letter in a given column did not differ, according to the Tukey test at a probability level of 5\%. ${ }^{(1)}$ For \\
statistical analysis the original values were transformed into log (x+1). & & &
\end{tabular}

With regard to yield rates, the best performing single-cross hybrids (HS83 $\times$ E3 $\left(7,108 \mathrm{~kg} \mathrm{ha}^{-1}\right)$ and D3 $\times$ F5 $\left.\left(7,048 \mathrm{~kg} \mathrm{ha}^{-1}\right)\right)$ did not differ; however, they differ from D4 $\times$ F4, F1 $\times$ D5, D1 $\times$ F2, and HS10 $\times$ E1, indicating a productivity potential under the low technological conditions used. Most single-cross hybrids exhibited positive heterosis for all characters. All hybrids showed heterosis relative to the higher parent, with the exception of the three- way cross hybrids HS10 $\times \mathrm{E} 1, \mathrm{HS} 32 \times \mathrm{E} 3$, and HS32 $\times$ E5. Heterosis was higher in single-cross hybrids, probably because the parentswere lines, whereas in the case of three-way cross hybrids one of the parents is a vigorous single-cross-cross hybrid (Table 3 ).

The lines and single-cross hybrids did not differ significantly with regard to $\mathrm{PH}, \mathrm{CH}, \mathrm{DW}, \mathrm{GY}$, and $\mathrm{COL}$; however, significant and positive correlations 
showed that the higher plant growth rates resulted in higher $\mathrm{CH}$ and $\mathrm{PH}$, and then in higher DW and GY (Table 4). COL correlated significantly and positively with all characters, with the exception of NS; however, some of the most productive genotypes exhibited low COL.

Table 3. Values of heterosis relative to the mean of the parents $(\mathrm{h}, \%)$ and heterosis relative to the superior parent (hs, $\%$ ) with regard to grain yield (GY) and colonization by autochthonous arbuscular mycorrhizal fungi (COL) in the corn hybrids.

\begin{tabular}{|c|c|c|c|c|}
\hline \multirow{2}{*}{ Hybrids } & \multicolumn{2}{|c|}{ GY } & \multicolumn{2}{|c|}{ COL } \\
\hline & $\mathrm{h}$ & hs & $\mathrm{h}$ & hs \\
\hline D3 x F5 & 429 & 372 & 5,85 & 1,46 \\
\hline F1 x D5 & 281 & 193 & 39,10 & 6,60 \\
\hline D2 x F4 & 166 & 106 & 73,37 & 67,80 \\
\hline HS $83 \times$ E3 & 122 & 49 & 20,65 & $-13,50$ \\
\hline F3 x D4 & 112 & 39 & 1,16 & $-18,12$ \\
\hline HS $10 \times$ E3 & 106 & 39 & 43,00 & 6,24 \\
\hline D1 x F2 & 80 & 49 & $-28,84$ & $-44,30$ \\
\hline HS $83 \times$ E1 & 76 & 24 & 24,84 & 14,96 \\
\hline HS $83 \times$ E5 & 60 & 12 & 64,58 & 54,55 \\
\hline HS 32 x E1 & 59 & 9 & 64,04 & 81,77 \\
\hline HS $10 \times$ E5 & 55 & 12 & $-13,20$ & $-13,82$ \\
\hline HS $32 \times$ E5 & 48 & 1 & 52,03 & 35,93 \\
\hline HS $32 \times$ E3 & 43 & -7 & 102,62 & 64,84 \\
\hline HS $10 \times$ E1 & -3 & -30 & $-22,16$ & $-24,34$ \\
\hline
\end{tabular}

Table 4. Diversity of autochthonous arbuscular mycorrhizal fungi (\%) before sowing and of the genotypes with superior grain and their respective parents.

\begin{tabular}{lrrrrrrc}
\hline FMA species & Antes & \multicolumn{1}{c}{ D3 } & \multicolumn{1}{c}{ F5 } & D3 x F5 & HS 83 & E3 & HS 83 x E3 \\
\hline Acaulospora longula & 8,74 & 0,00 & 1,18 & 0,00 & 0,00 & 0,00 & 0,00 \\
Acaulospora scrobiculata & 4,85 & 4,00 & 3,55 & 10,71 & 0,00 & 7,37 & 2,14 \\
Entrophospora colombiana & 29,13 & 17,60 & 11,83 & 45,23 & 15,79 & 16,84 & 8,56 \\
Glomus clarum & 5,82 & 11,20 & 10,06 & 4,76 & 2,63 & 1,05 & 3,21 \\
Glomus diaphanum & 18,45 & 3,20 & 1,78 & 1,19 & 0,88 & 1,05 & 1,60 \\
Glomus etunicatum & 0,97 & 7,20 & 11,24 & 4,76 & 0,00 & 2,11 & 3,74 \\
Glomus macrocarpum & 0,97 & 11,20 & 4,14 & 0,00 & 1,75 & 0,00 & 5,88 \\
Glomus margarita & 2,91 & 0,00 & 1,78 & 0,00 & 0,00 & 2,11 & 3,21 \\
Glomus sp. & 9,71 & 0,80 & 0,00 & 3,57 & 0,00 & 0,00 & 0,00 \\
Scutellospora calospora & 5,82 & 34,40 & 51,48 & 23,81 & 68,42 & 60,00 & 58,29 \\
Scutellospora gilmorei & 1,94 & 0,80 & 1,18 & 1,19 & 0,88 & 1,05 & 2,14 \\
Scutellospora pellucida & 10,68 & 9,60 & 1,78 & 4,76 & 9,65 & 8,42 & 11,23 \\
Total & 100 & 100 & 100 & 100 & 100 & 100 & 100 \\
\hline Species richness & 12 & 10 & 11 & 9 & 7 & 9 & 10 \\
\hline
\end{tabular}


Costa et al. (2001) reported differential responses between Miró and Barbados Malpighia emarginata D.C. genotypes, inoculated with distinct AMF species, with the Barbados genotype and Gigaspora margarita combination exhibiting the highest plant growth. According to the authors, the efficiency of the AMF-Malpighia emarginata plant association was affected by the genotypes of both symbionts. This indicates that the degree of interaction between the fungus and the plant depends greatly on the plant's genotype and that a specific combination between plant and fungus are advantageous, regardless of colonization level (JANOS, 1996).

Before sowing, analysis of AMF species richness showed the presence of 12 species (Table 2). The most abundant was Entrophospora colombiana (29.1\%), followed by Glomus diaphanum (18.45\%), and Scutellospora pellucida (10.68\%). Of these, the percentage of Entrophospora colombiana in the soil was higher in the presence of the D3 $\times$ F5 singlecross hybrid (45.23\%) and was the second most frequent in all lines. The percentage of Scutellospora calospora, which was present in the soil before sowing $(5.82 \%)$, increased the most, in the presence of every corn genotype tested, and was the most abundant species associated with the D3 (34.4\%), F5 (51.48\%), HS 83 (68.42\%), and E3 (60\%) lines, as well as with the HS $83 \times$ E3 single-cross hybrid (58.29\%). The percentages of the remaining fungal species (10) were increased poorly in the presence of all lines and hybrids included in the study (varying between $0 \%$ and $11.24 \%$ ).

These results show the preference of fungal species for specific hosts, in this case, the genotypes. Preferential associations were also reported by Carrenho et al. (2002), who described 10 AMF species in a corn crop, with a predominance of Acaulospora longula (46.5\%), Glomus claroideum (17.4\%), and Entrophospora colombiana (15.4\%). Oliveira et al. (2009) observed that different corn genotypes exhibit different $\mathrm{P}$ absorption capacity and that the plant's genotype has a greater impact on the mycorrhizal community than the level of $\mathrm{P}$ in the soil.

The analysis of mycorrhizal diversity among hybrids and their progeny showed the following predominance of species: Entrophospora colombiana followed by Scutelospora calospora in the D3 × F5 hybrid; Scutellospora calospora followed by Entrophospora colombiana in the parent lines D3 and F5; and Scutellospora calospora in the HS $83 \times$ E3 hybrid and their parent lines. Scutellospora calospora was the most abundant species in association with all genotypes, with the exception of the D3 $\times$ F5 hybrid (Table 2).

With regard to species richness, 12 species were present before sowing. The number of species in association with the D3 $\times$ F5 hybrid was lower than that of species associated with their parent lines (D3 and F5): 9, 10, and 11 species, respectively. Moreover, the HS $83 \times$ E3 hybrid and the parent lines (HS 83 and E3) were colonized by 10, 7, and 9 species, respectively (Table 2). Carrenho et al. (2001) observed the presence of 25 species in areas with successive corn crops. In the present study, the number of species differed from that reported by other authors; however, it was similar to those described by Trufem and Bononi (1985) and Siqueira et al. (1989), who found nine and ten species in soils from the Cerrado region, respectively.

The number of AMF species found in the rhizosphere of a particular plant varies significantly, both for the same culture as between different plants, as shown in the literature. It has been suggested that a greater fungal diversity in an area improves the performance of plant species with regard to absorption of soil nutrients and water, since although there is no host specificity, the effects of symbiosis differ according to the plant-fungus combination (SILVA et al., 2014; COSTA et al., 2001; POUYÚROJAS et al., 2006).

Benedetti et al. (2005) observed that the genera Acaulospora and Glomus were the most abundant 
in corn crops and were dominant relative to the species of the genera Scutellospora and Gigaspora. Similar results were obtained in the present study. Even though Glomus diaphanum is commonly described as a species with low acidity tolerance (COLOZZI-FILHO; CARDOSO, 2000), it was the second most abundant in the soil before the start of the present study (18.45\%), and its percentage in the soil was slightly affected by all genotypes (varying between $0.88 \%$ and $3.2 \%$, whereas Entrophospora colombiana varied between $45.23 \%$ and $8.56 \%$ ).

Plant improvement can generate genotypes with different nutritional requirements and different nutrient absorption capacity (TRINDADE et al., 2001). Moreover, populations in the autochthonous AMF community and their interactions with superior genotypes need to be better understood. Therefore, the identification of genotypes, particularly pure lines, that exhibit highly contrasting mycorrhizal colonization, will allow the production of $\mathrm{F}_{1}$ and $\mathrm{F}_{2}$ generations and backcrossing with better understood genetic traits.

AMF affects processes such as plant performance (nutrient absorption processes), the diversity and abundance of plant communities, and processes related to ecosystem stability (BERBARA et al., 2006). In this sense, to achieve agricultural production sustainability, plant improvement and selection programs should aim to obtain genotypes that are less dependent on external input, that absorb maximum nutrients with low solubility, or originate from organic matter recycling, and that are able to develop root symbiosis with AMF (REIS et al., 2008).

Some AMF species rapidly colonize the host and sporulate abundantly, whereas others require more time to sporulate or exhibit little sporulation and persist in the environment mainly in their active form (mycelium) and not as spores (GOMIDE et al., 2009). This may explain the results obtained in the present study.

\section{Conclusions}

There were qualitative and quantitative changes in fungal composition as well as preferential associations between fungi and plants.

The AMF diversity analysis showed the presence of 12 species, with Scutellospora calospora and Entrophospora colombiana the most abundant in all treatments. Acaulospora longula, Glomus etunicatum, Glomus macrocarpum, and Gigaspora margarita exhibited preferential associations among the genotypes.

COL and GY differed among lines and singlecross hybrids and significant correlations between COL and DW and GY showed positive plant-AMF interactions.

GY heterosis was not correlated with colonization heterosis. The HS83 $\times$ E3 and D3 $\times$ F5 single-cross hybrids exhibited high GY, which indicates a positive productive potential under the technological conditions used.

\section{Acknowledgements}

We thank CAPES (Coordenação de Aperfeiçoamento de Pessoal de Nivel Superior) for the scholarship to the two first authors and the CNPq (Conselho Nacional de Desenvolvimento Cientifico e Tecnológico) for research awards to the last author.

\section{Referências}

BENEDETTI, T.; ANTONIOLLI, Z. I.; GIRACCA, E. M. N.; STEFFEN, R. B. Diversidade de fungos micorrízicos arbusculares na cultura do milho após uso de espécies de plantas de cobertura de solo. Revista de Ciências Agroveterinárias, Lages, v. 4, n. 1, p. 44-51, 2005.

BERBARA, R. L. L.; SOUZA, F. A.; FONSECA, H. M. A. C. Fungos Micorrízicos arbusculares: muito além da nutrição. In: FERNANDES, M. S. (Ed.). Nutrição mineral de plantas. Viçosa, MG: Sociedade Brasileira de Ciência do Solo, 2006. p. 53-88. 
CARRENHO, R.; SILVA, E. S.; TRUFEM, S. F. B.; BONONI, V. L. R. Successive cultivation of maize and agricultural practices on root colonization, number of spores and species of arbuscular mycorrhizal fungi. Brazilian Journal of Microbiology, São Paulo, v. 32, n. 4, p. 262-270, 2001.

CARRENHO, R.; TRUFEM, S.; BONONI, V. L. Effects of using different host plants on the detected biodiversity of arbuscular mycorrhizal fungi from an agroecosystem. Revista Brasileira de Botânica, São Paulo, v. 25, n. 1, p. 9-101, 2002.

CLARK, R. B.; ZETOS, K. Mineral acquisition by mycorrhizal maize grown on acid and alkaline soil. Soil Biology and Biochemistry, Oxford, v. 28, n. 10, 11, p. 1505-1511, 1996.

COLOZZI-FILHO, A.; CARDOSO, E. J. B. Detecção de fungos micorrízicos arbusculares em raízes de cafeeiro e de crotalária cultivada na entrelinha. Pesquisa Agropecuária Brasileira, Brasília, v. 35, n. 10, p. 20332042, 2000 .

COSTA, C. M. C.; MAIA, L. C.; CAVALCANTE, U. M. T.; NOGUEIRA, R. J. M. C. Influência de fungos micorrízicos arbusculares sobre o crescimento de dois genótipos de aceroleira (Malpighia emarginata D.C.). Pesquisa Agropecuária Brasileira, Brasília, v. 36, n. 6, p. 893-901, 2001.

EMPRESA BRASILEIRA DE PESQUISA AGROPECUÁRIA - EMBRAPA. Centro Nacional de Pesquisa de Solos. Sistema brasileiro de classificação de solo. Brasília: Embrapa-SP; Rio de Janeiro: Embrapa CNPS, 1999. $412 \mathrm{p}$.

GIANINAZZI, S.; GOLLOTE, A.; BINET, M. N.; TUINEN, D. V.; REDECKER, D.; WIPF, D. Agroecology: the key role of arbuscular mycorrhizas in ecosystem services. Mycorrhiza, Heidelberg, v. 20, n. 8, p. 519-530, 2010.

GOMIDE, P. H. O.; SANTOS, J. G. D.; SIQUEIRA, J. O.; SOARES, C. R. F. S. Diversidade e função de fungos micorrízicos arbusculares em sucessão de espécies hospedeiras. Pesquisa Agropecuária Brasileira, Brasília, v. 44, n. 11, p. 1483-1490, 2009.

GUTJAHR, C.; PARNISKE, M. Cell and developmental biology of arbuscular mycorrhiza symbiosis. Annual Review of Cell Developmental Biology, Palo Alto, v. 29, n. 1, p. 593-617, 2013.

HETRICK, B. A. D.; WILSON, G. W. T.; COX, T. S. Mycorrhizal response in wheat cultivars: relationship to phosphorus. Canadian Journal of Botany, Otawa, v. 74, n. 1, p. 19-25, 1996.
INSTITUTO BRASILEIRO DE GEOGRAFIA E ESTATÍSTICA - IBGE. Levantamento sistemático da produção agrícola. Rio de Janeiro: IBGE, 2008. Disponível em: <http://www.ibge.gov.br/home/estatistica/ indicadores/agropecuaria/lspa/lspa_200804comentarios. pdf>. Acesso em: 9 mar. 2014.

INSTITUTO FNP. Agrianual: anuário da agricultura brasileira. São Paulo, FNP, 2010. p. 520.

JANOS, D. P. Mycorrhizas, succession and the rehabilitation of deforested lands in the humid tropics. In: FRANKLAND, J. C.; MEGAN, N.; GADD, G. M. (Ed.). Fungi and environmental change. Cambridge: Cambridge University Press, 1996. p. 129-162. (British Mycological Society Symposium. v. 20).

KAEPPLER, S. M.; PARKE, J. L.; MUELLER, S. M.; SENIOR, L.; STUBER, C.; TRACY, W. F. Variation among maize inbred lines and detection of quantitative trait loci for growth at low phosphorus and responsiveness to arbuscular mycorrhizal fungi. Crop Science, Madison, v. 40, n. 2 , p. $358-364,2000$.

OLIVEIRA, F. A.; CAVALCANTE, L. F.; SILVA, I. F.; PEREIRA, W. E.; OLIVEIRA FILHO, J. F. C. Crescimento do milho adubado com nitrogênio e fósforo em um Latossolo Amarelo. Revista Brasileira de Ciências Agrárias, Recife, v. 4, n. 3, p. 238-244, 2009.

PHILLIPS, J. M.; HAYMAN, D. S. Improved procedures for clearing roots and staining parasitic and vesiculararbuscular mycorrhizal fungi for rapid assessment of infection. Transactions of the British Mycological Society, London, v. 55, n. 1, p. 158-161, 1970.

POUYÚ-ROJAS, E.; SIQUEIRA, J. O.; SANTOS, J. G. D. Compatibilidade simbiótica de fungos micorrízicos arbusculares com mudas de espécies arbóreas tropicais. Revista Brasileira de Ciência do Solo, Viçosa, MG, v. 30, n. 3, p. 413-424, 2006.

RAIJ, B. van; ANDRADE, J. C.; CANTARELLA, H.; QUAGGIO, J. A. Análise química para avaliação da fertilidade de solos tropicais. Campinas: Instituto Agronômico, 2001. 285 p.

REIS, E. F.; CARNEIRO, M. A. C.; SAGGIN-JÚNIOR, O. J.; ROTTA, D. A.; SOUSA, M. Y. Absorção de fósforo em doze genótipos de milho inoculados com fungo micorrízico arbuscular em solo de cerrado. Ciência Rural, Santa Maria, v. 38, n. 9, p. 2441-2447, 2008.

RILLIG, M. C. Arbuscular mycorrhizae and terrestrial ecosystem processes. Ecology Letters, Hoboken, v. 7, n. 8, p. 740-754, 2004.

RILLIG, M. C.; MUMMEY, D. L. Mycorrhizas and soil structure. New Phytologist, New Jersey, v. 171, n. 1, p. 41-53, 2006. 
SCHENCK, N. C.; PÉREZ, Y. Manual for the identification of VA mycorrhizal fungi. Gainesville: University of Florida, 1990. 241 p.

SCHUCH, L. F. Benefícios da associação com Glomus clarum e adubação fosfatada em cultivares crioulas de milho. 2013. Dissertação (Mestrado em Agrobiologia) Universidade Federal de Santa Maria, Santa Maria, RS.

SIlVA, C. F.; ARAÚJO, J. L. S.; SILVA, E. M. R.; PEREIRA, M. G.; SCHIAVO, J. A.; FREITAS, M. S. M.; SAGGIN-JUNIOR, O. J.; MARTINS, M. A. Comunidade de fungos micorrízicos arbusculares: diversidade, composição e glomalina em área revegetada com sesbânia. Revista Brasileira de Ciências do Solo, Viçosa, MG, v. 38, n. 2, p. 423-431, 2014.

SIQUEIRA, J. O.; COLOZZI-FILHO, A.; OLIVEIRA, E. Ocorrência de micorrizas vesículo-arbusculares em agro e ecossistemas de Minas Gerais. Pesquisa Agropecuária Brasileira, Brasília, v. 24, n. 12, p. 1499-1506, 1989.

SMITH, S.; READ, D. J. Mycorrhizal symbiosis. Amsterdam: Academic Press, 2008. p. 769.
STÜRMER, S. L.; SIQUEIRA, J. O. Diversity of arbuscular mycorrhizal fungi in Brazilian ecosystems. In: MOREIRA, F. M. S.; SIQUEIRA, J. O.; BRUSSAARD, L. (Ed.). Soil biodiversity in Amazonian and other Brazilian ecosystems. London: CABI Publishing, 2006. p. 206-236.

TEWARI, L.; JOHRI, B. N.; TANDON, S. M. Host genotype dependency and growth enhancing ability of VA-mycorrhizal fungi for Eleusine coracana (finger millet). World Journal of Microbiology and Biotechnology, Dordrecht, v. 9, n. 2, p. 191-195, 1993.

TRINDADE, A. V.; SIQUEIRA, J. O.; ALMEIRA, F. P. Dependência micorrízica de variedades comerciais do mamoeiro. Pesquisa Agropecuária Brasileira, Brasília, v. 36, n. 12, p. 1485-1494, 2001.

TRUFEM, S. F. B.; BONONI, V. L. R. Micorrizas vesículo-arbusculares de culturas introduzidas em áreas de cerrado. Rickia, São Paulo, v. 12, p. 165-187, 1985.

WALKER, C. The mycorrhizal and the herbarium: The preservation of specimens from VA mycorrhizal studies. In: NORTH AMERICAN CONFFERENCE ON MYCORRHIZA, 4., 1979, Fort Collins. Proceeding... Fort Collins: CSU, 1979. p. 96. 
